\title{
HUBUNGAN AKTIVITAS, STATUS EMOSIONAL DAN KUALITAS TIDUR DENGAN KUALITAS HIDUP LANSIA DI PANTI WERDHA BINA BHAKTI SERPONG TANGERANG TAHUN 2015
}

\author{
Puput Riyanti $^{1}$, Ns. Diah Ratnawati, M.Kep, Sp.kep.Kom² \\ S1 Keperawatan Fakultas Ilmu-ilmu Kesehatan \\ Universitas Pembangunan Nasional "Veteran" Jakarta \\ Jln. Limo Raya, Depok \\ E-mail :puputriyanti7@yahoo.com
}

\begin{abstract}
Quality of life is one of the evaluation used to measure the level of a person's life with emphasis on an objective evaluation. Quality of life is affected by internal and external factors. internal factors are the experiences I've ever experienced before one of them is the emotional status, while external factors are all activities that dilakuakan everyday individuals like daily activities and sleep quality. This study was conducted to determine whether there is a relationship between activity, emotional status and quality of sleep and quality of life of the elderly. This study used crosssectional design, the sample used 63 respondents using purposive sampling technique. The results showed no activity relationship $(P=0.000, C I=95 \%)$ and emotional status $(0.03, C I=95 \%)$ with the quality of life in the elderly. The results also show no relationship quality of sleep $(P=$ $0.929, C I=95 \%$ ) with the quality of life in the elderly. Research suggests the nurse gerontik to get better at doing nursing care to the elderly, especially with regard aspects of activity and emotional status to improve the quality of life of the elderly.
\end{abstract}

Keywords: Elderly, activity, emotional status, sleep quality, quality of life.

\section{PENDAHULUAN}

Lansia adalah seorang baik laki-laki maupun perempuan yang berusia 60 tahun atau lebih (Kementerian Sosial RI, 2008). Lansia mengalami berbagai proses psikososial akibat proses penuaan. Proses penuaan pada lansia didasarkan oleh berbagai teori. Salah satunya teori Kontinuitas atau perkembangan, menyatakan bahwa seiring penuaan, kepribadian akan tetap sama dan perilaku menjadi lebih mudah diramalkan (Neugarten, 2009).
Lansia mengalami pertumbuhan dan perkembangan, diantaranya adalah menyesuaikan diri dengan menurunnya kekuatan fisik dan kesehatan, menyesuaikan diri dengan masa pensiun dan berkurangnya penghasilan (income) keluarga, menyesuaikan diri dengan kematian pasangan hidup, membentuk hubungan dengan orang-orang seusia, membentuk pengaturan kehidupan fisik yang memuaskan dan menyesuaikan diri dengan peran 
sosial secara leluasa (Hurlock, 2005). Program yang telah dilakukan pemerintah untuk lansia antara lain : pelayanan sosial, pemberdayaan sosial, bantuan dan pemeliharaan taraf kesejahteraan sosial (Depsos RI, 2005).

Populasi lansia di dunia mengalami peningkatan pesat. Sepanjang tahun 2000, populasi lansia dunia tumbuh lebih dari 795.000 setiap bulan dan diperkirakan lebih dari dua kali lipatnya pada tahun 2025.Pada saat itu akan terdapat lebih dari 800 juta orang berusia diatas 65 tahun, dan dua pertiga dari mereka berada di negara berkembang (Papalia, 2008).

Populasi lansia di Indonesia mencapai 16 juta jiwa pada tahun 2002.Data sensus Badan Pusat Statistik pada tahun 2000 menunjukkan bahwa jumlah penduduk lansia sebanyak 15.054.877 jiwa. Tahun 2007 menunjukkan bahwa jumlah lansia di Indonesia mencapai 18,96 juta jiwa (Statistik Indonesia, 2010). Jumlah populasi lansia di provinsi Banten saat ini kurang lebih mencapai14.647 orang. Diantaranya di Kota Tangerang sebanyak 4.480 jiwa dan di Kabupaten Tangerang 2.018 jiwa situasional misalnya adanya persepsi terhadap suatu ancaman, sedangkan komponen kognitif contohnya orang akan berfikir bagaimana cara-cara menyelamatkan diri dari bahaya. (Saam dkk, 2012).

Kualitas hidup pada lansia tentunya dipengaruhi juga pada kualitas tidur lansia. Tidur adalah dimana individu dalam keadaan tidak sadar dan dimana persepsi serta reaksi individu terhadap lingkungan menurun atau hilang dan dapat dibangunkan kembali dengan indra atau rangsangan yang cukup (Asmadi, 2008).

Menurunnya kualitas tidur pada lansia akan berdampak buruk terhadap kesehatan, karena dapat menyebabkan kerentanan terhadap penyakit, stress, konfusi, disorientasi, gangguan mood, kurang fresh, menurunnya kemampuan berkonsentrasi dan kemampuan membuat keputusan (Potter and Perry, 2009).

Berdasarkan data diatas, Indonesia termasuk salah satu negara berkembang yang saat ini merupakan 
lima besar di dunia terbanyak jumlah penduduk lanjut usianya.

Peningkatan jumlah penduduk lansia ini akan membawa dampak terhadap berbagai kehidupan. Dampak utama peningkatan lansia ini adalah peningkatan ketergantungan lansia. Ketergantungan ini disebabkan oleh kemunduran fisik, psikis dan sosial lansia yang digambarkan melalui empat tahap, yaitu kelemahan, keterbatasan, kemunduran fungsional, ketidakmampuan dan keterhambatan yang akan dialami bersamaan dengan proses kemunduran akibat proses menua. Dampak proses kemunduran akibat proses menua juga akan mempengaruhi kualitas hidup lansia.

Kualitas hidup adalah salah satu evaluasi yang digunakan untuk mengukur tingkat hidup seseorang dengan menekankan pada evaluasi yang objektif (De Geest, 2006). Penelitian yang dilakukan oleh Jeklin Linda Tambariki (2012), tentang Latihan fisik dan kualitas hidup lansia di kecamatan Dimembe kabupaten Minahasa utara, menyatakan bahwa ada hubungan yang signifikan antara latihan fisik dan kualitas hidup pada lansia. Penelitian selanjutnya oleh Shintya (2012) tentang pengaruh kualitas tidur pada kualitas hidup lansia penderita penyakit kronis di Rumah Sakit Advent Manado, menyatakan bahwa ada pengaruh dalam hal jenis kelamin dari kualitas tidur pada kualitas hidup manula pada aspek spiritual dan mental.

Penelitian tersebut menjadi dasar kesimpulan bahwa kualitas hidup pada lansia dipengaruhi oleh beberapa faktor diantaranya: aktivitas, status emosional dan kualitas tidur. Aktivitas fisik adalah setiap gerakan anggota tubuh yang dihasilkan atau digerakkan oleh otot rangka dan memerlukan energi. Aktivitas yang tidak ada (kurangnya aktivitas/ gerakan fisik) merupakan faktor risiko independen untuk penyakit kronis dan secara keseluruhan diperkirakan menyebabkan kematian secara global (WHO, 2010). Contoh aktivitas sehari-hari yang berkaitan dengan aktivitas fisik adalah berbelanja, melakukan aktivitas ringan, membersihkan rumah, mencuci pakaian dan lain-lain. Kualitas hidup pada lansia tentunya dipengaruhi juga pada keadaan status 
emosional lansia. Emosi adalah keadaan terangsang (aroused state) pada situasi atau kejadian. Keadaan tersebut memiliki komponen fisiologik, situasional dan komponen kognitif. Contoh : emosi takut mempengaruhi fisiologik seperti muka pucat, denyut jantung dan nafas bertambah cepat.

\section{METODE PENELITIAN}

Penelitian ini menggunakan metode cross sectional dengan desain Deskriptif kuantitatif digunakan untuk mengetahui hubungan aktivitas, status emosional dan kualitas tidur dengan kualitas hidup lansia di Panti Werdha Bina Bhakti Serpong Tangerang. Dalam desain Deskriptif kuantitatif pengumpulan data mulai dari variabel independent, variabel perancu dan variabel dependent dikumpulkan dalam satu waktu.

Penelitian ini dilakukan di Panti Werdha Bina Bhakti Serpong Tangerang. Waktu penelitian dilaksanakan pada bulan Mei 2015. Keseluruhan lansia yang ada di panti yaitu sebanyak 75 lansia. Jenis teknik sampling yang digunakan dalam penelitian ini adalah non probability sampling yaitu teknik pengambilan sampel dengan tidak memberikan peluang yang sama dari setiap anggota populasi, yang bertujuan tidak untuk generalisasi, yang berasas pada probabilitas yang tidak sama (Notoatmdjo, 2010). Teknik pengambilannya menggunakan purposive sampling. Penelitian ini ingin mengetahui hubungan aktivitas, status emosional dan kualitas tidur dengan kualitas hidup, oleh sebab itu uji yang digunakan adalah uji chisquare. Jumlah sampel sebanyak 63 responden yang dipilih berdasarkan kriteria inklusi dan eksklusi.

Variabel independent pada penelitian ini adalah aktivitas, status emosional dan kualitas tidur, sedangkan variabel tergantung (dependent) adalah kualitas hidup serta variabel perancu adalah karakteristik responden (umur, jenis kelamin dan tingkat pendidikan). Instrument dalam penelitian ini menggunakan kuesioner yang memiliki standar baku antara lain: Barthel index, Skala Depresi Geriatric, Pittsburgh Sleep Quality Index dan WHOQOL Breff. Data-data yang sudah didapat dimasukkan 
dalam table tabulasi lalu diolah menggunakan SPSS dan dianalisis dengan menggunakan chi-square untuk mengetahui hubungan variabel dependen dan independent dengan tingkat kemaknaan $\mathrm{p}<0,05$.

\section{HASIL dan PEMBAHASAN}

Berikut akan disajikan hasil penelitian hubungan aktivitas, status emosional dan kualitas tidur dengan kualitas hidup lansia dip anti werdha bina bhakti serpong - tangerang tahun 2015.Tabel-tabel berikut akan dikelompokkan berdasarkan analisa univariat yang terdiri dari data kategorik dan numerik, sedangkan analisa bivariat akan dijabarkan satu persatu untuk mengetahui pengaruh variabel independen dengan dependen.

\section{Analisa Univariat}

a. Usia

Tabel 1.

Distribusi Frekuensi Usia Responden di Panti Werdha Bina Bhakti Serpong Tangerang Tahun 2015

\begin{tabular}{|c|c|c|}
\hline Usia & Jumlah & Presentase \\
\hline$\leq 70$ tahun & 25 & 39,7 \\
\hline$>70$ tahun & 38 & 60,3 \\
\hline Total & 63 & 100,0 \\
\hline
\end{tabular}

Tabel 1 diatas dapat dilihat bahwa responden yang berusia $\leq 70$ tahun sebanyak $25 \quad(39,7 \%)$ dan responden yang berusia $>70$ tahun $38(60,3 \%)$.

b. Jenis Kelamin

\section{Tabel 2.}

Distribusi Frekuensi Responden Berdasarkan Jenis Kelamin Pada Lansia di Panti Werdha Bina Bhakti Serpong - Tangerang Tahun 2015

\begin{tabular}{|c|c|c|}
\hline Jenis Kelamin & Jumlah & Presentase \\
\hline Laki-laki & 23 & 36,5 \\
\hline Perempuan & 40 & 63,5 \\
\hline Total & 63 & 100,0 \\
\hline
\end{tabular}

Tabel 4.2 diatas dapat dilihat bahwa $23(36,5 \%)$ responden adalah responden laki-laki dan 40 $(63,5 \%)$ responden adalah responden perempuan. Hasil analisis tersebut dapat dilihat bahwa lebih banyak lansia perempuan dibandingkan dengan responden laki-laki, karena dari hasil penelitian terlihat mayoritas responden adalah perempuan. 
c. Tingkat Pendidikan

Tabel 3.

Distribusi Frekuensi Responden Berdasarkan Tingkat Pendidikan Pada Lansia di Panti Werdha Bina Bhakti Serpong - Tangerang Tahun 2015

\begin{tabular}{|c|c|c|}
\hline Pendidikan & Jumlah & Presentase \\
\hline Pendidikan Rendah & 40 & 63,5 \\
\hline Pendidikan Tinggi & 23 & 36,5 \\
\hline Total & 63 & 100,0 \\
\hline
\end{tabular}

Tabel 4.3 diatas dapat dilihat bahwa $40(63,5 \%)$ responden berpendidikan rendah dan $23(36,5 \%)$ responden berpendidikan tinggi. Hasil analisis tersebut dapat dilihat bahwa lebih banyak responden yang berpendidikan rendah dari pada responden yang berpendidikan tinggi.

\section{d. Aktivitas}

Tabel 4

Distribusi Frekuensi Responden Berdasarkan Aktivitas Pada Lansia di Panti Werdha Bina Bhakti Serpong - Tangerang Tahun 2015

\begin{tabular}{|c|c|c|}
\hline Aktivitas & Jumlah & Presentase \\
\hline Mandiri & 38 & 60,3 \\
\hline Tergantung & 25 & 39,7 \\
\hline Total & 63 & 100,0 \\
\hline
\end{tabular}

Tabel 4.4 diatas dapat dilihat bahwa $38(60,3 \%)$ responden melakukan aktivitas secara mandiri dan 25
$(39,7 \%)$ responden melakukan aktivitas secara ketergantungan atau dengan bantuan orang lain. Hasil analisis tersebut dapat dilihat bahwa lebih banyak responden yang melakukan aktivitasnya secara mandiri dibandingkan dengan responden yang melakukan aktivitasnya dengan dibantu.

e. Status Emosional

Tabel 5.

Distribusi Frekuensi Responden Berdasarkan Status Emosional Pada Lansia di Panti Werdha Bina Bhakti Serpong - Tangerang Tahun 2015

\begin{tabular}{|c|c|c|}
\hline Status Emosional & Jumlah & Presentase \\
\hline Adaptif & 57 & 90,5 \\
\hline Maladaptif & 6 & 9,5 \\
\hline Total & 63 & 100,0 \\
\hline
\end{tabular}

Tabel 4.5 diatas dapat dilihat bahwa $57 \quad(90,5 \%)$ responden memiliki status emosional yang adaptif dan $6(9,5 \%)$ responden memiliki status emosional yang maladaptif. Hasil analisis tersebut dapat dilihat bahwa lebih banyak responden yang memiliki status emosional yang adaptif dibandingkan dengan responden yang memiliki status emosional yang maladaptif. 
f. Kualitas tidur

Tabel 6

Distribusi Frekuensi Responden

Berdasarkan Kualitas Tidur Pada

Lansia di Panti Werdha Bina Bhakti

Serpong - Tangerang Tahun 2015

\begin{tabular}{|c|c|c|}
\hline Kualitas Tidur & Jumlah & Presentase \\
\hline Baik & 42 & 66,7 \\
\hline Kurang Baik & 21 & 33,3 \\
\hline Total & 63 & 100,0 \\
\hline
\end{tabular}

Tabel 4.6 diatas dapat dilihat bahwa $42(66,7 \%)$ responden memiliki kualitas tidur yang baik dan $21 \quad(33,3 \%)$ responden memiliki kualitas tidur yang kurang baik. Hasil analisis tersebut dapat dilihat bahwa lebih banyak responden yang memiliki kualitas tidur yang baik dibandingkan dengan responden yang memiliki kualitas tidur yang kurang baik.

g. Kualitas Hidup

\section{Tabel 7}

Distribusi Frekuensi Responden Berdasarkan Kualitas Hidup Pada Lansia di Panti Werdha Bina Bhakti Serpong - Tangerang Tahun 2015

\begin{tabular}{|c|c|c|}
\hline Kualitas Hidup & Jumlah & Presentase \\
\hline Baik & 32 & 50,8 \\
\hline Kurang Baik & 31 & 49,2 \\
\hline Total & 63 & 100,0 \\
\hline
\end{tabular}

Tabel 4.7 diatas dapat dilihat bahwa $32(50,8 \%)$ responden memiliki kualitas hidup yang baik dan $31 \quad(49,2 \%) \quad$ responden memiliki kualitas hidup yang kurang baik. Hasil analisis tersebut dapat dilihat bahwa lebih banyak responden yang memiliki kualitas hidup yang baik dibandingkan dengan responden yang memiliki kualitas hidup yang kurang baik.

\section{Analisa Bivariat}

a. Hubungan usia dengan kualitas hidup

\section{Tabel 8}

Analisa Kualitas hidup Lansia Berdasarkan Usia Pada Lansia di Panti Werdha Bina Bhakti Serpong Tangerang Tahun 2015

\begin{tabular}{|c|c|c|c|c|c|c|c|c|}
\hline \multirow[t]{4}{*}{ Usia } & \multicolumn{4}{|c|}{ Kualitas Hidup } & \multirow{3}{*}{\multicolumn{2}{|c|}{ Total }} & \multirow{4}{*}{$\begin{array}{c}\text { OR } \\
(95 \% \\
\mathrm{CI})\end{array}$} & \multirow{4}{*}{$\begin{array}{c}\mathrm{P} \\
\text { Value }\end{array}$} \\
\hline & \multirow{2}{*}{\multicolumn{2}{|c|}{ Baik }} & \multirow{2}{*}{\multicolumn{2}{|c|}{$\begin{array}{c}\text { Kurang } \\
\text { Baik }\end{array}$}} & & & & \\
\hline & & & & & & & & \\
\hline & $\mathrm{N}$ & $\%$ & $\mathrm{n}$ & $\%$ & $\mathrm{~N}$ & $\%$ & & \\
\hline$\leq 70$ tahun & 25 & 100,0 & 0 & 0,0 & 25 & 100,0 & 5,429 & 0,000 \\
\hline$>70$ tahun & 7 & 18,4 & 31 & 81,6 & 38 & 100,0 & $2,780-$ & \\
\hline & & & & & & & 10,599 & \\
\hline Jumlah & 32 & 50,8 & 31 & 49,2 & 63 & 100,0 & & \\
\hline
\end{tabular}

Tabel 4.8 diatas dari 32 responden lanjut usia terlihat $32(100,0 \%)$ responden memiliki kualitas hidup baik dan $0 \quad(0,0 \%)$ responden memiliki kualitas hidup kurang baik. 
Selain itu, dari 29 responden lanjut usia tua terlihat $0 \quad(00,0 \%)$ responden memiliki kualitas hidup baik dan 29 (100,0\%) responden memiliki kualitas hidup kurang baik. Selain itu dari 2 responden usia sangat tua $0 \quad(00,0 \%)$ responden memiliki kualitas hidup baik dan $2(100,0 \%)$ responden memiliki kualitas hidup kurang baik.

Hasil uji statistik didapatkan nilai $\mathrm{P}$ value 0,000 berarti $\mathrm{P}$ value < 0,05 , sehingga dapat disimpulkan terdapat hubungan yang bermakna antara usia dengan kualitas hidup pada lansia di Panti Werdha Bina Bhakti Serpong - Tangerang. Hal tersebut berkaitan dengan penelitian terdahulu yaitu penelitian yang dilakukan oleh Ekawati Sutikno, (2012) tentang Hubungan antara fungsi keluarga dan kualitas hidup lansia.

Penelitian tersebut mengemukakan bahwa faktor usia mempunyai hubungan yang secara statistik signifikan dengan kualitas hidup. Lansia yang berusia 70 tahun ke atas memiliki kemungkinan untuk berkualitas hidup lebih buruk dari pada lansia berusia kurang dari 70 tahun. Penelitian yang dilakukan oleh Nurhasanah dkk (2009), tentang Hubungan tingkat depresi dengan kualitas hidup pada masyarakat daerah bencana pasca gempa bumi di kabupaten Sleman tahun 2008.

Penelitian tersebut mengemukakan bahwa faktor usia pada subjek penelitian menunjukkan hubungan yang sangat lemah dan berpola negatif, hasil uji statistik menunjukkan bahwa tidak ada hubungan yang signifikan antara faktor usia dengan kualitas hidup.

Kesimpulan dari kedua penelitian diatas adalah terjadinya perbedaan hasil penelitian tersebut disebabkan karena distribusi usia responden yang kurang variasi. Mayoritas usia pada penelitian ini lebih banyak responden yang berusia $>70$ tahun dan kebanyakan responden memiliki persepsi yang sama tentang kualitas hidupnya dengan responden lainnya.

b. Hubungan jenis kelamin dengan kualitas hidup 
Tabel 9

Analisa Kualitas hidup Lansia Berdasarkan Jenis Kelamin Pada Lansia di Panti Werdha Bina Bhakti Serpong - Tangerang Tahun 2015

\begin{tabular}{|c|c|c|c|c|c|c|c|c|}
\hline \multirow{3}{*}{$\begin{array}{c}\text { Jenis } \\
\text { Kelamin }\end{array}$} & \multicolumn{4}{|c|}{ Kualitas Hidup } & \multirow{2}{*}{\multicolumn{2}{|c|}{ Total }} & \multirow{3}{*}{$\begin{array}{l}\text { OR } \\
(95 \%) \\
\text { CI) }\end{array}$} & \multirow{3}{*}{$\begin{array}{c}\mathrm{P} \\
\text { Value }\end{array}$} \\
\hline & \multicolumn{2}{|c|}{ Balk } & \multicolumn{2}{|c|}{ Kurang Baik } & & & & \\
\hline & n & $\%$ & n & $\%$ & $\mathrm{~N}$ & $\%$ & & \\
\hline Laki-Iaki & 12 & 52,2 & 11 & 47,8 & 23 & 100,0 & 1,091 & 1,000 \\
\hline Perempuan & 20 & 50,0 & 20 & 50,0 & 40 & 100,0 & $0,391-$ & \\
\hline & & & & & & & 5,447 & \\
\hline Jumlah & 32 & 50,8 & 31 & 49,2 & 63 & 100,0 & & \\
\hline
\end{tabular}

Tabel 4.9 di atas dari 23 responden laki-laki terlihat $12 \quad(52,2 \%)$ responden memiliki kualitas hidup baik dan $11(47,8 \%)$ responden memiliki kualitas hidup kurang baik. Selain itu, dari 40 responden perempuan terlihat $20 \quad(50,0 \%)$ responden memiliki kualitas hidup baik dan $20 \quad(50,0 \%)$ responden memiliki kualitas hidup kurang baik. Hasil uji statistik didapatkan nilai $\mathrm{P}$ value 1,000 berarti $\mathrm{P}$ value $>0,05$, sehingga dapat disimpulkan tidak terdapat hubungan yang bermakna antara jenis kelamin dengan kualitas hidup pada lansia di Panti Werdha Bina Bhakti Serpong - Tangerang. Hal tersebut berkaitan dengan penelitian terdahulu yaitu penelitian yang dilakukan oleh Lea Andy Shintya, (2012), tentang
Pengaruh kualitas tidur pada kualitas hidup lansia penderita penyakit kronis di Rumah Sakit Advent Manado. Hasil penelitian menunjukkan bahwa tidak ada hubungan yang signifikan antara jenis kelamin dengan kualitas hidup lansia pada aspek fisik, mental dan sosial. Selain itu, hasil penelitian juga menunjukkan bahwa ada hubungan yang signifikan antara jenis kelamin dengan kualitas hidup pada aspek spiritual.

Kesimpulan dari penelitian tersebut adalah jenis kelamin pada aspek fisik, mental dan sosial tidak ada hubungan yang signifikan dengan kualitas hidup lansia, tetapi pada aspek spiritual jenis kelamin lebih memiliki hubungan yang signifikan dengan kualitas hidup lansia. Jenis kelamin pada penelitian ini kurang seimbang distribusi jenis kelaminnya, dimana mayoritas responden adalah responden perempuan sehingga tidak ada perbedaan persepsi yang signifikan antara kualitas hidup responden laki-laki dan responden perempuan. 
c. Hubungan jenis kelamin dengan kualitas hidup

\section{Tabel 10}

Analisa Kualitas hidup Lansia Berdasarkan Tingkat Pendidikan Pada Lansia di Panti Werdha Bina Bhakti Serpong - Tangerang Tahun 2015

\begin{tabular}{|c|c|c|c|c|c|c|c|c|}
\hline \multirow[t]{3}{*}{ Pendidikan } & \multicolumn{4}{|c|}{ Kualitas Hidup } & \multirow{2}{*}{\multicolumn{2}{|c|}{ Total }} & \multirow{3}{*}{$\begin{array}{c}\text { OR } \\
(95 \% \\
\text { CI) }\end{array}$} & \multirow{3}{*}{$\begin{array}{c}\mathrm{P} \\
\text { Value }\end{array}$} \\
\hline & \multicolumn{2}{|c|}{ Baik } & \multicolumn{2}{|c|}{ Kurang Baik } & & & & \\
\hline & $\mathrm{n}$ & $\%$ & $\mathrm{n}$ & $\%$ & $\mathrm{n}$ & $\%$ & & \\
\hline Rendah & 22 & 55,0 & 18 & 45,0 & 40 & 100,0 & 1,589 & 0,536 \\
\hline Tinggi & 10 & 43,5 & 13 & 56,5 & 23 & 100,0 & $0,565-$ & \\
\hline & & & & & & & 4,465 & \\
\hline Jumlah & 32 & 50,8 & 31 & 49,2 & 63 & 100,0 & & \\
\hline
\end{tabular}

Tabel 4.10 diatas dari 40 responden yang berpendidikan rendah terlihat $22 \quad(55,0 \%)$ responden memiliki kualitas hidup baik dan $18(45,0 \%)$ responden memiliki kualitas hidup kurang baik. Selain itu dari 23 responden yang berpendidikan tinggi terlihat $10(43,5 \%)$ responden memiliki kualitas hidup baik dan 13 (56,5\%) responden memiliki kualitas hidup kurang baik. Hasil uji statistik didapatkan nilai $\mathrm{P}$ value0,536 berarti $\mathrm{P}$ value $>0,05$, sehingga dapat disimpulkan tidak terdapat hubungan yang bermakna antara tingkat pendidikan dengan kualitas hidup pada lansia di Panti Werdha Bina Bhakti Serpong - Tangerang.
Hal tersebut berkaitan dengan teori yang dikemukakan oleh (Asep, 2007), yaitu umumnya setelah memasuki masa lansia maka akan mengalami penurunan fungsi kognitif dan psikomotor. Fungsi kognitif meliputi proses belajar, persepsi, pemahaman, pengertian, perhatian dan lain-lain sehingga menyebabkan reaksi dan perilaku lansia menjadi makin lambat. Penelitian yang dilakukan Aguswina Butar-Butar (2012), tentang Karakteristik pasien dan kualitas hidup pasien gagal ginjal kronik yang menjalani terapi hemodialisa.

Hasil penelitiannya mengatakan bahwa, pada responden yang memiliki pendidikan lebih tinggi akan mempunyai pengetahuan yang lebih luas juga memungkinkan responden itu dapat mengontrol dirinya dalam mengatasi masalah yang dihadapi, mempunyai rasa percaya diri yang tinggi, berpengalaman dan mempunyai perkiraan yang tepat bagaimana mengatasi kejadian, mudah mengerti tentang apa yang dianjurkan oleh petugas kesehatan, 
serta dapat mengurangi kecemasan

sehingga dapat membantu individu tersebut dalam membuat keputusan.

Hasil wawancara yang telah dilakukan pada responden yang berpendidikan tinggi maupun berpendidikan rendah, mayoritas memiliki pendapat yang sama tentang kualitas hidupnya sehingga hal tersebut menimbulkan hasil tidak adanya perbedaan yang signifikan antara tingkat pendidikan dengan kualitas hidup.

d. Hubungan aktivitas dengan kualitas hidup

\section{Tabel 11}

Analisa Kualitas hidup Lansia Berdasarkan Aktivitas Pada Lansia di Panti Werdha Bina Bhakti Serpong Tangerang Tahun 2015

\begin{tabular}{|c|c|c|c|c|c|c|c|c|}
\hline \multirow{3}{*}{ Aktivitas } & \multicolumn{4}{|c|}{ Kualitas Hidup } & \multirow{2}{*}{\multicolumn{2}{|c|}{ Total }} & \multirow{3}{*}{$\begin{array}{c}\text { OR } \\
(95 \% \\
\text { CI) }\end{array}$} & \multirow{3}{*}{$\begin{array}{c}\mathrm{P} \\
\text { Value }\end{array}$} \\
\hline & \multicolumn{2}{|c|}{ Baik } & \multicolumn{2}{|c|}{ Kurang Baik } & & & & \\
\hline & $\mathrm{N}$ & $\%$ & $\mathrm{~N}$ & $\%$ & $\mathrm{n}$ & $\%$ & & \\
\hline Mandiri & 32 & 84,2 & 6 & 15,8 & 38 & 100,0 & 0,158 & 0,000 \\
\hline ketergantungan & 0 & 0,0 & 25 & 100,0 & 25 & 100,0 & $\begin{array}{l}0,076- \\
0,329\end{array}$ & \\
\hline Jumlah & 32 & 50,8 & 31 & 49,2 & 63 & 100,0 & & \\
\hline
\end{tabular}

Tabel 4.11 diatas dari 38 responden yang beraktivitas mandiri terlihat $32 \quad(84,2 \%)$ responden memiliki kualitas hidup baik dan $6(15,8 \%)$ responden memiliki kualitas hidup kurang baik. Selain itu dari 25 responden yang berpendidikan tinggi terlihat $0(0,0 \%)$ responden memiliki kualitas hidup baik dan 25 $(100,0 \%)$ responden memiliki kualitas hidup kurang baik. Hasil uji statistik didapatkan nilai $\mathrm{P}$ value 0,000 berarti $\mathrm{P}$ value $<0,05$, sehingga dapat disimpulkan terdapat hubungan yang bermakna antara aktivitas dengan kualitas hidup pada lansia di Panti Werdha Bina Bhakti Serpong - Tangerang.

Hal tersebut berkaitan dengan penelitian terdahulu yaitu penelitian yang dilakukan oleh Jeklin Linda Tambariki, (2012), tentang Latihan fisik dan kualitas hidup lansia di kecamatan Dimembe kabupaten minahasa utara. Metode penelitian yang digunakan adalah Quasi eksperimental dengan design one group pre test-post test, dan rumus yang digunakan adalah chi-square contingency dan wilcoxon sign test. Responden dalam penelitian ini adalah lansia usia 60 tahun ke atas, pria dan wanita dan lansia potensial (mandiri) yang berdomisili di desa Laikit, Diembe, Warukapas, Tetey dan Lumpias. 
Jumlah respondent adalah 157 . Hasil aspek kualitas hidup menggunakan chs-square contingency yaitu 0,001. Pada penggunaan wilcoxon sign test, (1.000) mengacu pada nilai $(\alpha=0,05)$. Hasil penelitian ini menyatakan bahwa ada hubungan yang signifikan antara latihan fisik dan kualitas hidup pada lansia dan ada perbedaan yang signifikan pada kualitas hidup lansia jika ditinjau dari aspek fisik dan sosial. Sebaliknya, tidak ada perbedaan yang signifikan berdasarkan aspek mental dan spiritual.

Kesimpulannya, dibandingkan penelitian terdahulu dengan penelitian yang peneliti lakukan, perbedaannya adalah penelitian terdahulu menggunakan metode Quasi eksperimental dengan design one group pre test-post test, dan rumus yang digunakan adalah chi-square contingency dan wilcoxon sign test.Responden dalam penelitian tersebut adalah lansia usia 60 tahun ke atas, pria dan wanita dan lansia potensial (mandiri), sedangkan pada penelitian ini metode yang digunakan adalah cross sectional dengan rumus chi-square dan responden pada penelitian ini sebanyak 63 responden.

$$
\begin{aligned}
& \text { e. Hubungan status emosional } \\
& \text { dengan kualitas hidup }
\end{aligned}
$$

\section{Tabel 12}

Analisa Kualitas hidup Lansia Berdasarkan Status Emosional Pada Lansia di Panti Werdha Bina Bhakti

\begin{tabular}{|c|c|c|c|c|c|c|c|c|}
\hline \multirow{3}{*}{$\begin{array}{l}\text { Status } \\
\text { Emosional }\end{array}$} & \multicolumn{4}{|c|}{ Kualitas Hidup } & \multirow{2}{*}{\multicolumn{2}{|c|}{ Total }} & \multirow{3}{*}{$\begin{array}{l}\text { OR } \\
(95 \% \\
\text { CI) }\end{array}$} & \multirow{3}{*}{$\begin{array}{c}\text { P } \\
\text { Value }\end{array}$} \\
\hline & \multicolumn{2}{|c|}{ Baik } & \multicolumn{2}{|c|}{ Kurang Baik } & & & & \\
\hline & n & $\%$ & $N$ & $\%$ & N & $\%$ & & \\
\hline Adaptif & 26 & 45,6 & 31 & 54,4 & 57 & 100,0 & 0,456 & 0,035 \\
\hline Maladaptif & 6 & 100,0 & 0 & 0,0 & 6 & 100,0 & $0,344-$ & \\
\hline & & & & & & & 0,006 & \\
\hline Jumlah & 32 & 50,8 & 31 & 49.2 & 63 & 100,0 & & \\
\hline
\end{tabular}
Serpong - Tangerang Tahun 2015

Tabel 4.12 diatas dari 57 responden yang memiliki status emosional adaptif terlihat 26 $(45,6 \%)$ responden memiliki kualitas hidup baik dan 31 (54,4\%) responden memiliki kualitas hidup kurang baik. Selain itu dari 6 responden yang memiliki status emosional maladaptif terlihat 6 $(100,0 \%)$ responden memiliki kualitas hidup baik dan $0(0,0 \%)$ responden memiliki kualitas hidup kurang baik. Hasil uji statistik didapatkan nilai $\mathrm{P}$ value 0,035 berarti $\mathrm{P}$ value $<0,05$, sehingga 
dapat disimpulkan terdapat hubungan yang bermakna antara Status emosional dengan kualitas hidup pada lansia di Panti Werdha Bina Bhakti Serpong - Tangerang.

Hal tersebut berkaitan dengan teori yang dikemukakan oleh (Ryff, 2006) tentang aspek-aspek status emosional yang mempengaruhi tinggi rendahnya kualitas hidup. Aspek-aspek tersebut antara lain: (1) Self - Acceptance, memiliki sikap yang positif pada diri sendiri, menerima diri baik aspek yang positif maupun negatif, memandang positif masa lalu merasa tidak puas terhadap diri sendiri, kecewa dengan masa lalu, ingin menjadi orang yang berbeda dari dirinya sendiri. (2) Positive Relation with Others, merasa puas, percaya berhubungan dengan orang lain, memikirkan kesejahteraan orang lain, memiliki empati, affection dan intimacy, dalam suatu hubungan dapat saling mengerti, memberi, dan menerima tidak nyaman dekat dengan orang lain, merasa terisolasi dan frustasi juka berhubungan dengan orang lain, tidak bisa terikat dengan orang lain. (3) Autonomy, mandiri, maupun mempertahankan diri dari pengaruh luar (tidak konformitas), mampu mengatur diri, mampu mengevaluasi diri terlalu memperhatikan harapan, dan evaluasi dari luar, tidak membuat keputusan sendiri (minta bantuan dari orang lain untuk mengambil keputusan penting), konformitas. (4) Purpose in Life, memiliki tujuan hidup, merasakan masa kini dan masa lalu adalah berarti, memiliki keyakinan hidup kurang memiliki keberartian hidup, sedikit memiliki tujuan hidup, tidak menganggap tujuan hidupnya dimasa lalu, tidak memiliki keyakinan dalam hidup. (5) Personal Growth, selalu punya keinginan mengembangkan diri, terbuka dengan pengalaman baru, menyadari potensi yang dimiliki, selalu memperbaiki diri dan tingkah laku personal stagnation, tidak dapat meningkatkan dan mengembangkan diri, merasa jenuh dan tidak tertarik dengan kehidupan, merasa tidak mampu untuk mengembangkan sikap atau tingkah laku yang baru (Departemen Sosial, 2008). 
f. Hubungan kualitas tidur dengan kualitas hidup.

\section{Tabel 12}

Analisa Kualitas hidup Lansia Berdasarkan Kualitas Tidur Pada Lansia di Panti Werdha Bina Bhakti Serpong - Tangerang Tahun 2015

\begin{tabular}{|c|c|c|c|c|c|c|c|c|}
\hline \multirow[t]{4}{*}{ Kualitas Tidur } & \multicolumn{4}{|c|}{ Kualitas Hidup } & \multirow{3}{*}{\multicolumn{2}{|c|}{ Total }} & \multirow{4}{*}{$\begin{array}{c}\text { OR } \\
(95 \% \\
\text { CI })\end{array}$} & \multirow[t]{4}{*}{$\mathrm{P}$ Value } \\
\hline & \multirow{2}{*}{\multicolumn{2}{|c|}{ Baik }} & \multirow{2}{*}{\multicolumn{2}{|c|}{$\begin{array}{c}\text { Kurang } \\
\text { Baik }\end{array}$}} & & & & \\
\hline & & & & & & & & \\
\hline & $\mathrm{N}$ & $\%$ & $\mathrm{n}$ & $\%$ & $\mathrm{n}$ & $\%$ & & \\
\hline Baik & 22 & 52,4 & 20 & 47,6 & 42 & 100,0 & 1,210 & 0,929 \\
\hline Kurang Baik & 10 & 47,6 & 11 & 52,4 & 21 & 100,0 & $0,424-$ & \\
\hline & & & & & & & 3,454 & \\
\hline Jumlah & 32 & 50,8 & 31 & 49,2 & 63 & 100,0 & & \\
\hline
\end{tabular}

Tabel 4.13 diatas dari 42 responden yang memiliki kualitas tidur baik terlihat $22 \quad(52,4 \%)$ responden memiliki kualitas hidup baik dan $20(47,6 \%)$ responden memiliki kualitas hidup kurang baik. Selain itu dari 21 responden yang memiliki kualitas tidur kurang baik terlihat $10(47,6 \%)$ responden memiliki kualitas hidup baik dan $11 \quad(52,4 \%)$ responden memiliki kualitas hidup kurang baik. Hasil uji statistik didapatkan nilai $\mathrm{P}$ value 0,929 berarti $\mathrm{P}$ value $>0,05$, sehingga dapat disimpulkan tidak terdapat hubungan yang bermakna antara kualitas tidur dengan kualitas hidup pada lansia di Panti Werdha Bina Bhakti Serpong - Tangerang.
Hal tersebut berkaitan dengan penelitian terdahulu yaitu penelitian yang dilakukan oleh Shintya, (2012), tentang Pengaruh kualitas tidur pada kualitas hidup lansia penderita penyakit kronis di Rumah Sakit Advent Manado.

Tujuan penelitian ini adalah untuk mengidentifikasi pengaruh kualitas tidur pada kualitas hidup lansia penderita penyakit kronis ditinjau dari aspek fisik, mental, sosial dan spiritual serta untuk mengetahui apakah ada perbedaan pengaruh kualitas tidur pada kualitas hidup lansia penderita penyakit kronis pria dan wanita ditinjau dari aspek fisik, mental, sosial dan spiritual. Design penelitian adalah deskriptif korelasi dengan tehnik purposive sampling.

Hasil penelitian menunjukkan bahwa tidak ada pengaruh yang signifikan dari kualitas tidur pada kualitas hidup lansia ditinjau dari aspek fisik, mental, sosial, dan spiritual dan tidak ada pengaruh jenis kelamin dari kualitas tidur pada kualitas hidup manula pada aspek fisik, mental dan sosial. 
Penelitian yang dilakukan oleh Kurnia (2007), tentang Aromaterapi bunga lavender mempengaruhi kualitas tidur pada lansia. Penelittian tersebut mengatakan bahwa kualitas tidur mempengaruhi kualitas hidup dan berhubungan dengan angka mortalitas yang lebih tinggi.

Kesimpulannya adalah dari kedua penelitian terdahulu dan penelitian yang peneliti lakukan bahwa kualitas tidur mempengaruhi hanya beberapa aspek-aspek dari kualitas hidup lansia.

\section{KESIMPULAN}

Sesuai dengan pembahasan hasil penelitian yang dilakukan kepada 63 responden di Panti Werdha Bina Bhakti Serpong Tangerang yang masuk dalam kriteria inklusi responden maka dapat disimpulkan sebagai berikut:

a. Sebagian besar responden lansia di Panti Werdha Bina Bhakti Serpong - Tangerang terdiri dari lanjut usia, lanjut usia tua dan usia sangat tua dan mayoritas responden berusia lanjut yaitu usia 60 sampai 74 tahun $(50,8 \%)$. Jenis kelamin responden terdiri dari laki-laki dan perempuan, mayoritas responden perempuan (63,5\%). Tingkat pendidikan responden terdiri dari pendidikan rendah (SD, SMP) dan pendidikan tinggi (SMA, PT) dan mayoritas responden berpendidikan rendah $(63,5 \%)$.

b. Aktivitas responden dibagi menjadi 2 yaitu, mandiri dan tergantungan, mayoritas responden beraktivitas mandiri $(60,3 \%)$.

c. Status emosional responden terdiri dari adaptif dan maladaptif, mayoritas responden berstatus emosional adaptif $(90,5 \%)$.

d. Kualitas tidur responden terdiri dari kualitas tidur baik dan kurang baik dan mayoritas kualitas tidur responden baik $(66,7 \%)$.

e. Kualitas hidup responden dibagi menjadi 2 yaitu, baik dan kurang baik dan mayoritas responden berkualitas hidup baik $(50,8 \%)$.

f. Ada hubungan yang bermakna antara usia responden dengan kualitas hidup responden di Panti Wherda Bina Bhakti Serpong Tangerang, dan tidak ada hubungan yang bermakna antara jenis kelamin dan tingkat pendidikan responden dengan kualitas hidup responden di Panti 
Wherda Bina Bhakti Serpong Tangerang.

g. Ada hubungan yang bermakna antara aktivitas responden dengan kualitas hidup responden di Panti Wherda Bina Bhakti Serpong Tangerang.

h. Ada hubungan yang bermakna antara Status Emosional responden dengan kualitas hidup responden di Panti Wherda Bina Bhakti Serpong Tangerang.

i. Tidak ada hubungan yang bermakna antara kualitas tidur responden dengan kualitas hidup responden di Panti Wherda Bina Bhakti Serpong Tangerang.

\section{SARAN}

Hasil penelitian yang telah dilakukan, terdapat beberapa hal yang perlu direkomendasikan untuk penelitian yang terkait dengan topik penelitian ini yaitu :

a. Bagi Lansia.

Lansia perlu memperhatikan segala aspek-aspek dalam kehidupannya khususnya aktivitas dan status emosional pada usia tua agar tercapai kualitas hidup yang baik. b. Bagi Keluarga.

Keluarga perlu memperhatikan tugas-tugas perkembangan keluarga dalam merawat lansia supaya keluarga juga dapat membantu lansia dalam mencapai kualitas hidup yang lebih baik.

c. Bagi Panti Werdha.

Panti werdha disarankan untuk tetap mempertahankan kinerja asuhan keperawatannya dalam merawat lansia, khususnya perlu memperhatikan lansia lebih intensif lagi dari aspek status emosionalnya supaya tercapai kualitas hidup lansia yang lebih baik lagi.

d. Bagi Perawat Gerontik.

Perawat gerontik supaya lebih memperhatiakan dan memahami status emosional yang dimiliki oleh lansia dan asuhan keperawatan apa yang harus diterapkan perawat gerontik terhadap lansia.

e. Bagi Dinas Sosial.

Dinas sosial disarankan untuk melindungi lansia dari tindak kekerasan, eksploitasi dan perlakuan yang salah serta menyediakan pelayanan sosial dan kemudahan untuk mengakses 
fasilitas umum bagi penduduk lanjut usia.

f. Bagi Institusi Pendidikan.

Institusi Pendidikan perlu melakukan usaha-usaha untuk meningkatkan pengetahuan aktivitas, status emosional dan kualitas tidur lansia serta hubungannya dengan kualitas hidup lansia.

g. Bagi Penelitian Selanjutnya.

Penelitian lebih lanjut, direkomendasikan untuk penelitian yang lain adalah area penelitian dapat dikembangkan dengan jumlah populasi lebih banyak dan jumlah variabel yang diteliti juga ditambah, sehingga dapat menghasilkan hasil yang lebih akurat. Analisa data yang digunakan untuk penelitian berikutnya tidak hanya pada analisa univariat dan bivariat saja, tetapi dapat dilakukan analisa secara multivariat.

h. Bagi Peneliti

Peneliti sebaiknya menggunakan quesioner dengan kata-kata yang mudah dipahami oleh lansia dan memperhatikan kebutuhankebutuhan lansia ketika sedang melakukan penelitian.

\section{REFERENSI}

Abu Hamadi. 2009. Psikologi Umum. Salemba Medika: Jakarta

Arianti K. 2014. Hubungan antara Dukungan Sosial dan Kualitas Hidup pada Lansia Penderita Hipertensi.

Darmojo, Boedhi, Hadi Martono. 2006. Buku Ajar Geriatri (Ilmu Kesehatan Usia Lanjut). Balai Penerbit Fakultas kedokteran Universitas Indonesia: Jakarta.

Dharma, Kelana Kusuma. 2011. Metodologi Penelitian Keperawatan Panduan Melaksanakan dan Menerapkan Hasil Penelitia., CV.Trans Info Media : Jakarta

Hidayat, Alimul Aziz. 2008. Metode Penelitian Keperawatan dan Teknik Analisis Data. Salemba Medika: Jakarta

Macken C, Lynda. 2012. Partners Together in Health: HealthRelated Quality of Life Outcomes in Coronary Artery Bypass Patients and Partners. Omaha: University of Nebraska, Doctor of Philosophy: Dissertation

Maryam dkk. 2008. Mengenal Usia Lanjut dan Perawatanny., EGC: Jakarta

Menulis artikel dan karya ilmiah 2015, Diakses 20 Maret 2015 Jam: $\quad 9.40 \quad$ WIB http://digilib.ump.ac.id/files/di 
sk1/19/jhptump-a-rustosigit904-2-babii.pdf

Menulis artikel dan karya ilmiah 2015, Diakses 20 Maret 2015 Jam: $\quad 9.45 \quad$ WIB http://digilib.ump.ac.id/files/di sk1/12/jhptump-a-maulianura$\underline{\text { 570-2-babii.pdf }}$

Menulis artikel ilmiah dan karya ilmiah 2015. Diakses 29 Maret 2015 Jam:19.46WIBhttp://eprints.u nsri.ac.id/2522/1/Kualitas_tid ur_dan_Gangguan_Tidur_pad La nsia.....pdf

Mikey Stanley \& Beare. 2006. Buku Ajar Keperawatan Gerontik Edisi 2. EGC: Jakarta

Notoatmodjo. 2010. Metodologi Penelitian Kesehatan. PT Rineka Cipta: Jakarta

Potter and Perry. 2009. Fundamental of Nursing Edisi 7. Salemba Medika: Jakarta

Programme On Mental Health. WHOQOL-BREF:

Introduction, Administration, Scoring and Generic Version of The Assesment. Field Trial Version. Geneva: World Health Organization, 1996.

Rustika, 2010, 'Profil Penduduk Lnjut Usia di Indonesia' volume $\mathrm{X}$ nomer 2 tahun 2010.

Setiadi. 2013. Konsep dan Praktik Penulisan Riset Keperawatan Edisi 2. Graha Ilmu: Yogyakarta
Setyoadi dkk, 2010, Perbedaan Tingkat Kualitas Hidup pada Wanita Lansia di Komunitas dan Panti.

Stuart. 2006. Buku Saku Keperawatan Jiwa Edisi 5. EGC: Jakarta

Sutanto P dan Luknis S. 2010. Statistik Kesehatan. PT.Raja Grafindo Persada: Jakarta

Sutanto P. 2007.Analisis Data Kesehatan. Fakultas Kesehatan Masyarakat Universitas Indonesia: Jakarta

Suseno, Imam dkk. 2013. Pengantar Statistika untuk Penelitian Pendidikan. Unindra Press: Jakarta

Tempo.com. 2011.Belasan Ribu Lansia Terancam Terancam di Banten. 11 November 2011, diakses 9 Maret 2015. http://www.tempo.co/read/ne $\mathrm{ws} / 2011 / 11 / 09 / 179365719 / \mathrm{Be}$ lasan-Ribu-Lansia-Terancam$\underline{\text { Terlantar-di-Banten }}$

The Barthel Index. 2005. Di Unduh dari www.strokecenter.org Tanggal 9 April 2015 Jam: 13.54

WHO (Quality of Life) Bref. 2004. Kualitas Hidup. Diunduh dari http://www.who.int tanggal 29 Maret 2015 Jam: 19.46 WIB

Wahyuni dkk.2009. Kualitas Tidur dan Gangguan Tidur pada Lansia di Panti Werdha Bakti Dharma KM. 7 Palembang. JKK, Th 41, No. 1. 
Yenny. 2013. Hubungan Aktivitas Sehari-hari dan Successful Aging pada Lansia.' Vol.4, No 5.

Zulfan S dan Wahyuni. 2012. Psikologi Keperawatan. PT. Raja Grafindo Persada: Depok

Yuliati dkk. 2014.'Perbedaan Kualitas Hidup Lansia yang Tinggal di Komunitas dengan di Pelayanan Sosial Lanjut Usia' Vol.2, No.1, hlm. 87-94. 